\title{
The influence of the organizational and environmental factors on the Amazon family
}

\section{farming enterprises in Brazil}

\author{
A influência dos fatores organizacionais e ambientais sobre a agricultura familiar amazônica \\ brasileira
}

La influencia de los factores organizacionales y ambientales en las empresas de agricultura familiar amazónica en Brasil

\author{
Alexandre Jorge Gaia Cardoso \\ ORCID: https://orcid.org/0000-0001-5878-4328 \\ State University of Pará, Brazil \\ E-mail: alexandregaia@yahoo.com.br \\ Osvaldo Ryohei Kato \\ ORCID: https://orcid.org/0000-0002-2422-9227 \\ Embrapa Amazônia Oriental, Brazil \\ E-mail: osvaldokato@gmail.com \\ Pedro Antônio de Melo \\ ORCID: https://orcid.org/0000-0001-7607-4303 \\ Federal University of Santa Cartarina, Brazil \\ E-mail: pedro.inpeau@gmail.com \\ Daniel Nascimento-e-Silva \\ ORCID: https://orcid.org/0000-0001-9770-575X \\ Federal Institute of Education, Brazil \\ E-mail: danielnss @gmail.com
}

\begin{abstract}
This study analyzed whether organizational and environmental factors influence the management of productive units of Amazonian family farmers. The method used consisted of an in-depth study of 32 communities in the northeast of Pará, using questionnaires, whose data were analyzed using Pearson's correlation analysis, and structured interviews, whose data were analyzed with French help technique of content analysis. The results showed the variables that most influence the management of the productive units are financial, among the organizational factors, and the economic and environmental, among the environmental factors. The conclusion showed that the surveyed family farmers' precapitalist mentality is the main impediment to achieving their business success.
\end{abstract}

Keywords: Cutting and grinding; Tipitamba; New technologies; Without burning agriculture; Family farmers.

\section{Resumo}

Este estudo analisou se os fatores organizacionais e ambientais influenciam na gestão das unidades produtivas dos agricultores familiares amazônicos. O método utilizado consistiu em um estudo aprofundado de 32 comunidades do Nordeste do Pará, por meio de questionários, cujos dados foram analisados pela análise de correlação de Pearson, e entrevistas estruturadas, cujos dados foram analisados com auxílio da técnica francesa de análise de conteúdo. Os resultados mostraram que as variáveis que mais influenciam a gestão das unidades produtivas são as financeiras, entre os fatores organizacionais, e as econômicas e ambientais, entre os ambientais. A conclusão mostrou que a mentalidade pré-capitalista dos agricultores familiares pesquisados é o principal impedimento para o sucesso empresarial.

Palavras-chave: Corte e trituração; Tipitamba; Novas tecnologias; Agricultura sem queima; Agricultores familiares.

\section{Resumen}

Este estudio analizó si factores organizacionales y ambientales influyen en el manejo de las unidades productivas de los agricultores familiares amazónicos. El método utilizado consistió en un estudio en profundidad de 32 comunidades en el noreste de Pará, mediante cuestionarios, cuyos datos fueron analizados mediante el análisis de correlación de Pearson, y entrevistas estructuradas, cuyos datos fueron analizados con ayuda francesa técnica de análisis de contenido. Los resultados mostraron que las variables que más influyen en la gestión de las unidades productivas son las financieras, entre los factores organizacionales, y las económicas y ambientales, entre los ambientales. La conclusión mostró que la mentalidad precapitalista de los agricultores familiares encuestados es el principal impedimento para lograr el éxito empresarial.

Palabras clave: Cortar y moler; Tipitamba; Nuevas tecnologías; Agricultura sin quemar; Agricultores familiares. 


\section{Introduction}

In the Amazon, family farming is practiced over several centuries based on the traditional knocking down and burning of the secondary fallow vegetation, called capoeira (Sampaio, 2008). Although it is an aggressive practice for the environment, the burning resource is the traditional technology that has the task of feeding 400,000 small farmers in the northeastern region of Para, the object of this study. The study by Sampaio (2008) shows that previously treated under the logging and burning logic, family farming allows the incorporation of a new form of land use capable of manipulating the ecosystem's structural components. This new technology incorporates the organic residues of the vegetation into the soil while at the same time preventing the emission of carbon from increasing the productivity of the farmers, technology known as agriculture without burning or grinding of capoeira without burning (Embrapa, 2002).

The technology consists of triturating biomass of secondary vegetation and its use as mulch for crops. This process avoids the loss of nutrients by burning vegetation and improves the chemical, physical, and biological soil conditions by adding organic matter and flexibility to the agricultural calendar. Due to more excellent retention of soil moisture, and creates the possibility of consecutive cultivation periods, increasing the intensity of land use (Embrapa, 2002).

It turns out that the low technological level of Brazilian family farmers, especially in the Amazon, can not be explained only by the lack of adequate technology. On the contrary, in many cases, even when the technology is available, it does not benefit the farmer due to lack of managerial capacity and favorable environmental conditions for its application (Batalha et al., 2005). To use new technology, family farmers do not consider only one parameter to guide their options, although another element may significantly influence the decision process (Santos, 2006). For the author, cultural aspects such as local knowledge and beliefs, the available means of production (inputs, tools), and the relationship with the environment, among others, are examples of criteria of choice that influence these subjects' preferences techniques. It reinforces the need to strengthen the organization of the farmers in Igarapé-Açu within a systemic approach.

The activities carried out under this project have been carried out in specific areas, with studies emphasizing aspects such as impacts of fire use. It is essential to point out that capoeira is the most critical capoeira species to determine capoeira's effect on capoeira development (Denich, 1991; Denich et al., 2004; Hölscher, 1997). Few studies have focused on management or external factors of family farmers, including data collection, information generation, and decision-making based on management techniques, reinforcing that this phenomenon is not treated satisfactorily in the national and international literature. That is why it still resists the crucial question that still does not find a consistent answer: why do Amazonian family farmers fail to achieve productive and economic-financial self-sustainability?

Work in this area is almost always restricted to financial and economic aspects. Even when talking about the issue of agricultural technologies and their adoption by family farmers, such as the system of cutting and grinding, studies that deal with management are directed only at economical costs (Costa, 2006; Michelotti, 2006; Bevilacqua, 2006), as if management were restricted to economic-financial aspects.

Likely, cutting and grinding technology developed to enable sustainable agriculture in the Amazon will be incompatible with local farmers' conditions, both financially and by the lack of experience and capacity to manage the property. Farmers' network is part of the Tipitamba project. For effective use of managerial tools and procedures, actors need to perceive them as necessary.

The studies of perception seek to know how much specific facts and phenomena of the world are perceived as necessary or not by research subjects. These studies assume that the greater the perception of the importance of these facts and phenomena, the greater the likelihood that they may be considered in their daily practical attitudes. From the managerial point of view, the more critical the organizational and environmental variables are considered by family farmers who practice production without burning their businesses, the greater the likelihood of these variables being taken as guidelines for their 
actions. In this sense, this article aims to analyze if the organizational and environmental factors are considered necessary by the family farmers practicing the production without burning to manage their productive units.

\section{Production Without Burning and Management}

Cutting and burning agriculture is a way of cleaning the areas by removing vegetation and plant biomass from the soil surface by preparing it to receive the crops. This type of agriculture fire has some effects: to fertilize the soil with nutrient sources of the ashes when burning vegetation (Gliessman, 2001). However, what appears to be a positive effect at the first moment with time becomes negative. While burning the fallow vegetation, there is a decrease in the biomass above and below the ground (Hölscher, 1997). It is due to the loss of nutrients such as nitrogen, carbon, and sulfur, potassium, phosphorus, magnesium, and sodium. Over time, this process decreases the soil's initial fertility associated with increasing invasive plants makes new crops unviable (Santos, 2006).

This type of agriculture is currently carried out on approximately $30 \%$ of the world's arable land, despite the limiting factors caused by the cutting and burning method. It provides a livelihood for an estimated population of more than 250 million people (Costa, 2005). The same author noted that this area preparation method is essential, both economically - responsible for approximately $80 \%$ of total food production in the region and the number of people directly or indirectly dependent on it (Costa, 2005).

The use of land for planting by family farmers using the system of cutting and burning of secondary fallow vegetation was the object of the project SHIFT-Capoeira result of the partnership Brazil-Germany later denominated of Tipitamba. The researchers involved in the project developed a technology capable of shredding secondary vegetation biomass by incorporating such vegetation's organic residues into the soil and avoiding carbon emission using fire (Santos, 2006; Sampaio, 2008).

The SHIFT-Capoeira project, Tipitamba, was part of the SHIFT Program (Studies on Human Impact in Flowers and Floodplains in the Tropics) and entitled "Capoeira with fallow vegetation in Agriculture in the Eastern Amazon: function and the possibility of Management." This project was carried out through bilateral cooperation between the Ministry of Science and Technology of Germany (BMBF) and the Ministry of Science and Technology of Brazil through the National Council for Scientific and Technological Development $(\mathrm{CNPq})$, the Embrapa Amazônia Oriental, and the Universities of Bonn and Göttingen (Sampaio, 2008; Oliveira, 2002; Santos, 2006).

The technology proposed by the Tipitamba project consists of cutting and grinding the secondary vegetation. This technique was initially performed with manual cutting of vegetation and trituration in a forage harvester. Later, the Tritucap crusher prototype was developed by the University of Göttingen, Germany, coupled with a tractor, cut, and grind. Parallel to this was sought in the Brazilian market, some implement that carried out this work. The search resulted in two forest mills models existing in the national market, which can be used as capoeira crushers (Santos, 2006; Sampaio, 2008; BNDES, 2011). These implements cut and grind the biomass of the secondary vegetation without destroying its root system and, at the same time, distributes this material onto the soil. After crushing, the soil is covered by a layer of crushed plant material with a height of approximately $6.3 \mathrm{~cm}$ (Bervald, 2001).

The adoption of new technologies in agriculture involves social, demographic, cultural, social, and political variables as decisive and essential factors for adoption (Moxley \& Lang, 2006; Ma, Grübler and Nakamori, 2009). For Dereti (2009), technology can only be considered transferred when incorporated. It can modify it, adapt it, increase it according to its necessity, or identify and channel a new research demand, boosting the technological succession to identify environmental factors. 
In the process of technological adoption, the potential adopter is not a passive unit but an active decision-maker. For Ghadim and Pannell (1999), the adoption of technological innovation involves the development of skills (management of a culture, for example), the reduction of uncertainty about the profitability of innovation in the long term, personal perceptions of the farmer about the benefits of innovation, managerial skills, risk preferences in addition to social and demographic factors. According to the authors, the availability of labor, age, experience, and geographic distance are essential factors in adopting technologies by family farmers.

Bandiera and Rasul (2002) studied the adoption of technologies in Northern Mozambique and found that the probability of adoption is higher among farmers who reported having discussed agriculture with others. Besley \& Case (1993) studied a community in India and found that, since farmers discover the actual yield from adopting new technologies, they are more likely to adopt them.

Foster and Rosenzweig (1995), studying technology adoption in India, found that farmers may not adopt new technology due to insufficient knowledge about the management of new technologies. However, adoption occurs due to own experiences and neighbors. Similarly, Conley \& Udry (2002) studied pineapple cultivation in Ghana and analyzed whether the farmer's individual fertilizer use responds to information on his neighbor's fertilizer's productivity. They demonstrated here the importance of social learning about productivity.

Anselmi (2012) shows that the high cost of equipment, tools, lack of qualified personnel make it difficult to adopt new agricultural technologies. Therefore it is necessary to develop among research institutions, teaching, private companies, suppliers of equipment, consultants, service providers, and power to achieve more satisfactory technology adoption results.

Sanders and Lynam (1982) evaluated the adoption of agricultural technologies in Colombia and found a gap between technologies developed by research institutions and their use in agricultural units. It is necessary to carry out tests in the agricultural units themselves to overcome this situation. Such strategies allow more outstanding communication between farmers and researchers and increase farmers' experience with technology management. From this strategy, farmers can suggest changes and adaptation in developed technology.

Cribb et al. (2011) showed that integrating technology with agriculture corresponds to effective technological adoption, including selection, acquisition, implementation, and technology absorption. In a paper on agricultural innovation, Feder et al. (1985) define the final adoption as the degree of new technology in long-term equilibrium when the farmer has full information about the new technology and its potential. Agreeing with this definition, Rauniyar \& Goode (1992) acknowledge that farmers are not likely to reach final adoption in the short term. For them, the need for time is explained by how farmers begin to experiment with one or more technological practices until they reach a balance of use.

Moxley and Lang (2006) studied the influence of the social context of Jamaican farmers' communities on the sustainable (long-term) use of new agricultural technologies. Unlike studies that attribute this sustainable use to factors such as the size of the agricultural area, income, age, and schooling of the farmer, the authors attribute this relation to socioeconomic factors. These factors are the roads that allow access to buses, farmers' involvement with local institutions, church and community capacity to process a large amount of information.

According to Uaiene (2011), in a study carried out in Mozambique, families with access to technical assistance services, with access to rural credit, and agricultural associations are more likely to adopt new agricultural technologies. According to the author, to increase the probability of adopting modern agricultural technologies by family farmers, public managers must mobilize to overcome the deficiencies of the agricultural credit market, increase access to technical assistance services through extension and farmer associations as improved education.

The question of farmers' organization for adopting technological innovations through vegetation grinding machines in substituting traditional agricultural production technologies in Amazonia was also studied by Kawage (2006). Social 
participation, interconnectivity between social systems, exposure to interpersonal communication channels, and a high social interconnection system are positively associated with the anticipated adoption of innovations. For the author, even if the technology is beneficial from an ecological and economic point of view, if the local structures of the systems of organizational and institutional systems are not conducive to real adoption, it will be unfeasible (Kawage, 2006). For the author, since the equipment and operation costs make the individual use of technology unfeasible, collective use is the only way to enable small producers' adoption. The collective use of the resource (capoeira grinding machine) must be managed collectively by the local farmers' organization.

Agricultural technology is the result of the systematic application of scientific knowledge to productive activities. In a more operational sense, according to the authors, scientific knowledge can be applied to a good or knowledge of how to carry out culture or creation (Ramalho \& Contini, 1987). Cutting and grinding technology is an example of the successful application of scientific knowledge focused on agriculture and natural resources sustainability. Its adoption and expansion have been a challenge involving access to resources and strengthening farmers' organization through management (Sampaio, 2008).

Managing an organization means making it work. The operation takes place through a process (Stoner \& Freeman, 1999). The process is a logical sequence of steps that generate a given product (Nascimento-e-Silva, 2011; 2013; Nascimentoe-Silva et al., 2020a; 2020b). The management process steps are to plan, organize, direct, and control (Megginson et al., 1998). These steps are about organizational resources. Because these resources are scarce, they need to be planned, organized, managed, and controlled; otherwise, the organization's objectives will be challenging to achieve (Nascimento-e-Silva, 2011; 2013).

The lack of a management system that supports local farmers' organizations in Igarapé-Açu weakens, for example, marketing practices in local agriculture. Family farmers become more dependent on so-called intermediaries who buy the products on the farm itself, usually paying the price well below market value. In many cases, cross-breeders anticipating the payment of production assume the role of financiers of productive activities and supply the family's immediate needs, reinforcing the dependence of local farmers on this agent (BNDES, 2011). In Igarapé-Açu city, for example, even though producers have a wide variety of fruits. They cannot take advantage of regional fruits' current opportunities necessary to diversify the municipalities' economic base. More than 27 fruit pulp agroindustries exist only in the metropolitan and northeast mesoregions of Paraense (Santana et al., 2008).

It is necessary to overcome the restriction of scale imposed by the small production area to exploit all the advantages of family agriculture technologies. It is necessary to add value to production and create adequate marketing channels. Thus, it will be possible to increase production scale, gain bargaining power, and reach markets that alone would be inaccessible to the family farmer (Batalha et al.

Pavarina et al. (2003) carried out a study to show the importance of rural producers' administrative activities (planning, organization, direction, and control). They drew attention to differences of opinion between producers and the technicians who assist them (agronomists, veterinary technicians, and agricultural technicians). For the author, these differences may make it challenging to improve management in rural properties. The author identified significant differences of opinion regarding the functions of "planning" and "organization." Although the producers perform these functions for the author, most of them are "in the head," which is little discussed or shown to relatives or third parties, like technical assistance members.

The commercialization had a more divergent opinion than the others about the operational areas (production, marketing, finance, and human resources). The author explains that this difference is related to the fact that the technical courses emphasize productive aspects, so it may be that the rural producer replaces technical recommendations with the practical experience obtained in years of experience in rural enterprise decisions (Pavarina et al.). 
Cella (2002) highlights the importance of the financial factor for the success of the rural enterprise. This factor should be understood not as greater availability of monetary resources but rather as the farmer's competence, ability, and attitude who collaborates to manage financial resources efficiently. The reason for this is that the successful farmer is the one who knows how to manage the resources available to him. He knows when to use his own or third-party resources, he knows when it is advantageous for him to buy and sell insight or the future, knows how to delineate a strategy of investments or expenses in the short and long term. It is also confirmed by a study conducted by Cribb et al. (2011) on the adoption of new technology by an organization of coconut water farmers in the State of Rio de Janeiro, where it is presented the need to organize farmers through strategies to overcome the individual constraints of each farmer.

\section{Methodology}

This research is exploratory because it aims to provide the researcher with greater familiarity with the problem (Gil, 2002; Vergara, 2007). The objective is to clarify the organizational and systemic factors that interfere with adopting secondary vegetation technology by the Tipitamba farmers in Igarapé-Açu. It describes why it aims to describe the interviewees' perceptions, expectations, and suggestions (Vergara, 2007; Nascimento-e-Silva, 2012) regarding the factors that hinder technology use's satisfactory progress. The information was collected locally with the Tipitamba farmers in Igarapé-Açu. There were subsidies to explain the unsatisfactory progress in adopting the technology by farmers from identifying the management and systemic factors.

The research approach was both quantitative and qualitative. The quantitative approach starts from quantifying by translating data into opinions and information with statistical resources and techniques. The qualitative method starts from a view in which there is no intention of numbering or measuring homogeneous units or categories (Oliveira, 1997). The methodological routing of the research, based on Sá et al. (2004), was divided into three steps, presented in Figure 1.

Figure 1: Search Chaining.

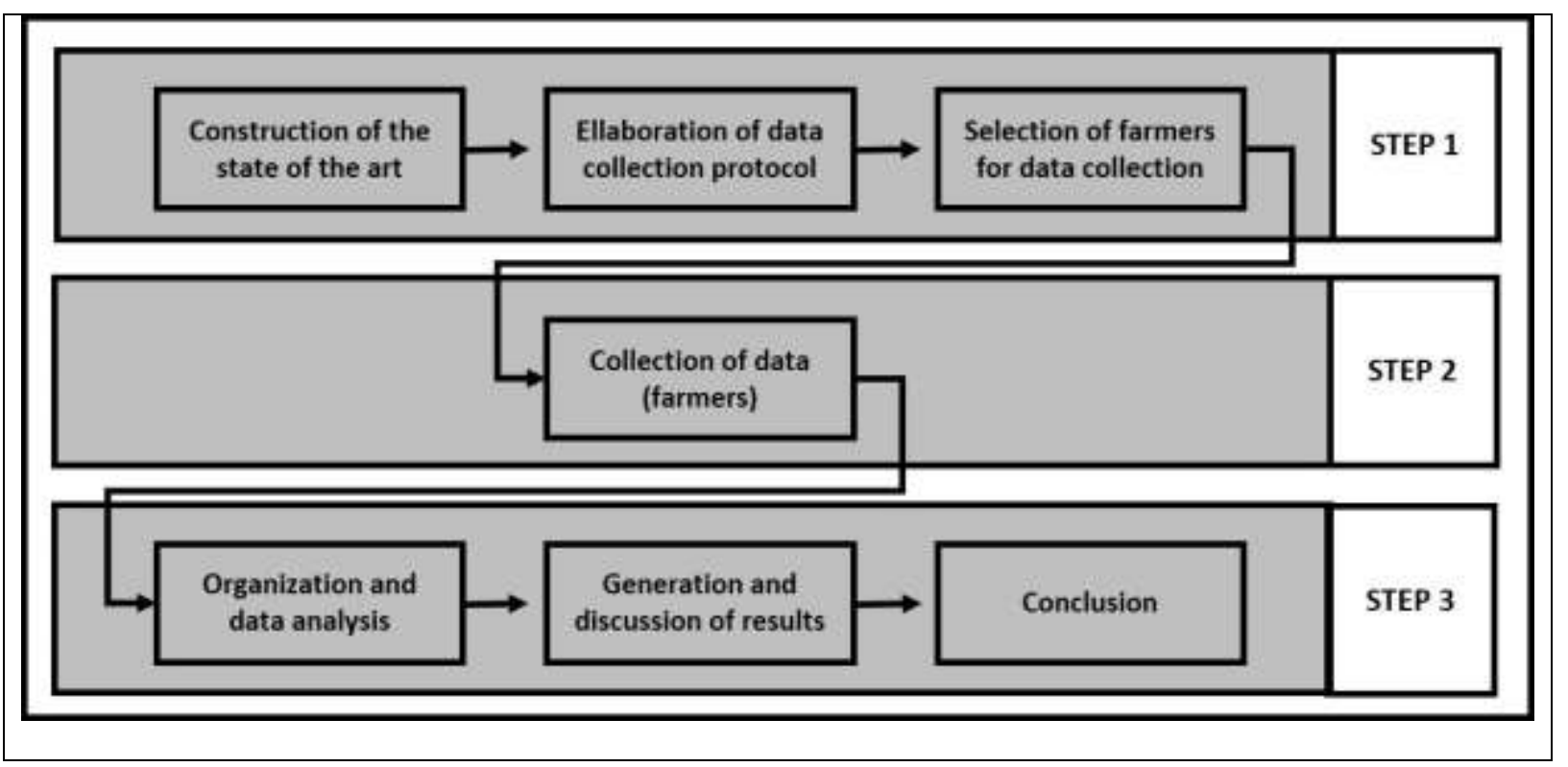

Source: Adapted from Sá, Cruz, and Nascimento-e-Silva (2004).

The data presented in the research came from two sources: primary and secondary. Primary source because the data were collected from farmers in four communities in the municipality of Igarapé-Açu and are part of Tipitamba: Nova Olinda, Nossa Senhora do Rosário, São João, and Novo Brasil. The interest for these communities in Igarapé-Açu was because they 
are located in the region where the Tipitamba Project is more active. In Igarapé-Açu, all project phases are concentrated, from the origin, development, and current stage, so a better understanding of agriculture's problems without burning can be obtained.

Data collection was done through interviews, discussion workshops, and questionnaires, as suggested by Nascimentoe-Silva (2020a; 2020b), Silva et al. (2020), and Limas, Santiago and Nascimento-e-Silva (2020). Access to the interviewees was possible due to the openness given by the coordination of the Tipitamba project. It coincided with developing a research project on the management model for farmers approved in Public Notice 006/2010 of the Amazônia Paraense Foundation of Amparo to Research (FAPESPA) of innovation to family agriculture.

The data collection instrument used in the research was composed of a questionnaire divided into five (5) blocks alternating open and closed questions. Questions are closed because the respondent does not respond freely; choose from the available options. In the open questions, the informant has complete freedom to express their opinion on a particular subject. The first block identified the characteristics of the farmer and the property; (administrative, human, productive, marketing, financial, logistic) factors that hamper the advancement of crushing technology, the fourth external factors (economic, social, political, cultural, environmental, legal, demographic, technological). The fifth block identified other factors that interfere with farmers' adoption of the technology.

Each dimension was divided into five (5) items presented on a Likert scale. This scale turned the question into a statement. The respondent was asked to select an alternative that would best represent their opinion, obeying scores ranging from 1 to 5,1 for never a problem and 5 for always a problem.

After the fieldwork results, the questionnaires were typed in spreadsheets, and then the statistical calculations of Pearson's correlation were performed. After these procedures, a correlation study of internal and external environment variables was performed.

Correlation analysis is fascinating when one wants to know the degree of relationship between variables. Correlations measure how much a variable A influences another variable $\mathrm{B}$. When one has a large number of variables, and if one wants to know the degree of association of two to two, the correlation matrix is usually used. Pearson's correlation coefficient is used to quantify the association's intensity and direction between the variables (Figueiredo Filho \& Silva Júnior, 2009; Sensuse et al., 2015, Gaidos, 2015, and Salleh, 2015).

It is important to emphasize that correlation does not mean cause and effect relationship, but the only similarity between the distribution of the variables' scores. Pearson's correlation presents scores ranging from -1 to +1 ; the correlation is direct and negative when it is inverse. Regarding the values, when under 0.5 , the correlation was considered weak. Values between 0.5 and 0.7 were moderate, and above 0.7, it was interpreted as strong. From the interpretative point of view, when the correlation is considered weak, it shows its importance for managing the familiar farmers' productive units. When considered moderate, it will mean that farmers sometimes take them into account in their managerial practices. When it is considered strong, it will be interpreted as being taken into account in these farmers' business conduct.

The correlation between organizational and environmental factors is summarized in tables. In the first column are listed the variables analyzed in each factor. The second is the intensity of the correlation represented by the coefficient of $r$ Pearson. The last column presents the p-value, which shows that the correlations are statistically significant at $5 \%$. That is, we reject the null hypothesis that the presented variables are not correlated. The organizational factors are administrative, productive, commercial / marketing, financial, and logistics; the environmental factors are economic, social, political, cultural, technological, demographic, and environmental. Each factor was measured from the variables that compose it. 


\section{Results and Discussion}

A total of 32 farmers were interviewed in-depth using the cutting and grinding system in Igarapé-Açu and are distributed as follows: $31.25 \%$ are from the community of São João, 31.25\% Nova Olinda, 25\% from Novo Brasil, and $12.50 \%$ of Our Lady of the Rosary, all communities of the municipality of Igarapé-Açu, in the northeast of Para. As for age, 38\% are between 41 and 50,31\% are between 51 and 60,16\% are over 61, 13\% are between 31 and 40, and 3\% are between 20 and 30 years. It means that most family producers are adults, with a strong tendency towards old age.

About the production unit's size, $84 \%$ has an area of up to 30 hectares, $9 \%$ has between 31 and 40 hectares, and $6 \%$ has between 51 and 60 hectares. These results show that almost all are holders of small rural properties and that they will hardly be able to obtain from the small estates the returns that allow them financial self-sufficiency without using technology. The farmers are involved in cutting and grinding secondary vegetation is $66 \%$ between 6 and 10 years, $25 \%$ less than five years, and $9 \%$ between 11 and 15 years. The experience with the technology used is consolidated by $91 \%$ of the interviewed farmers, which allowed them to respond adequately to the questions asked and, at the same time, to validate the results contained herein.

The practices of cultivation without the use of the fire are $63 \%$ of them plant cassava, corn, rice, fruits, vegetables, and small trees; $25 \%$ plant cassava, corn, rice, fruits, and vegetables; $13 \%$ planted cassava, corn, rice, fruits, vegetables, and medium-sized trees. Despite the small properties, the products can apply the principle of crop variety in their production systems, perhaps because of the Amazonian soil's low fertility. That monoculture could be harmful to them.

\subsection{Organizational factors}

The correlation between the organizational factors is summarized in Table 1. Concerning the administrative grouping, the variables "Control vs. Communication", "Control vs. Organization", and "Communication and Planning" presented the following correlations: $0,48,0,41$, and 0,35 respectively, or are direct correlations with the weak force. Probably when the farmer makes better control or organization of the resources in his property, there can be gains, both in terms of productivity, the use of technology without burning, and improvement of the living conditions of his family, which probably can catch the attention of (Batalha et al., 2005). This paper presents its results, but this perception is still fragile, shared by a small part of the respondents.

It requires the intensification of communication with other neighboring farmers or agricultural technicians to increase social learning (Conley \& Udry, 2002). On the other hand, the more intense communication between farmers, agricultural technicians, and other partners generates information that can be used to plan and make decisions regarding production, market, suppliers, logistics, and other essential aspects to strengthen local agricultural management and organization. This practice can likely raise the actors' perception in the essential communication between them.

For the human group, for the variables "Value vs. Working day," the correlation is 0.36 , considered a direct weak. This result shows that sometimes the higher the farmer's value from the sale of his production, the more likely he will be to increase his working day due to the greater motivation influenced by the financial factor. It means that the more you work, the more value you tend to receive. Although not the only one, it is assumed that the economic factor is one of the primary motivators to increase workers' productivity. But this presumption is not perceived by the family farmers surveyed.

In the productive group, the variables that presented a moderate direct correlation were "Capoeiras x Available area," with 0.50 , while "Delay to grind the area vs. capoeira" showed a weak direct correlation of 0.35 . The more considerable the amount of secondary vegetation, the greater the area available for trituration by Tritucap. Capoeira originates from the total abandonment of the area used after developing agriculture activities and is an essential agroecosystem component for agriculture without burning in northeast Pará (Sampaio, 2008). 
For this reason, it plays a vital role in forest growth, biomass accumulation, erosion control, nutrient conservation, hydrological benefits, and biodiversity maintenance. Therefore, the more secondary vegetation and the more available area to crush and practice agriculture without burning. And this, by all accounts, is perceived by a highly statistically significant number of farmers.

The correlation between delay in grinding and capoeira shows that the capoeira tries to grow when this type of situation occurs. The vegetation is not crushed, which increases the farmer's dissatisfaction, compromises the agricultural calendar, the productivity of the area, the practice of agriculture without burning, and in some cases leads the farmer to practice burning the area again for lack of choice. However, since the correlation is weak, this chain of consequences is not perceived by the family farmers surveyed.

Table 1: Organizational factors correlated by $r$ Pearson.

\begin{tabular}{l|c|c}
\hline Factors and Variables & r Pearson & p-value \\
\hline Administrative & 0,48 & 0,0056 \\
Control vs. Communication & 0,41 & 0,0200 \\
Control vs. Organization & 0,35 & 0,0464 \\
Communication vs. Planning & & \\
\hline Human & 0,36 & 0,0427 \\
\hline Palue vs. Working Day & & \\
Capoeira Area vs. Available area & 0,50 & 0,0034 \\
Delay to grind the area vs. Capoeira area & 0,35 & 0,0469 \\
\hline Marketing & & \\
Identification of potential customers vs. Price quote & 0,34 & 0,0489 \\
\hline Financial & & \\
Identification of profits/losses vs. Revenues & 0,59 & 0,0004 \\
Identification of profits/losses vs. Costs & 0,58 & 0,0004 \\
Identification of profits/losses vs. Expenses & 0,47 & 0,0067 \\
\hline Logistics & & \\
Storage/transport vs. Customers & 0,49 & 0,0041 \\
Storage vs. Packing & 0,47 & 0,0070 \\
Storage vs. Customers & 0,43 & 0,0135 \\
Storage/transport vs. Transport & 0,37 & 0,0350 \\
\hline
\end{tabular}

Source: Authors.

The variables "Identification of potential customers vs. Price quotation" showed a weak direct correlation in the marketing group, with 0.34 . When farmers are probably aware of potential customers to sell their products other than intermediaries, they are more likely to quote their prices. When selling to the middleman and creating a relationship of dependence, Igarapé-Açu does not take advantage of the fact that the region produces a rich diversity of fruits (BNDES, 2011; Santana et al., 2008). Although this logic is crystal clear for the literature and experts, unfortunately, family farmers still do not realize it, as shown by the very weak correlation of 0.34 .

In the finance grouping, the variables "Profit/Loss identification vs. revenue," "Profit/Loss identification $\mathrm{x}$ Cost identification," and "Profit/loss identification vs. Expense identification" presented the following scores 0.59, 0.58, and 0.47, respectively (the first two being strong direct correlations and the last being weak direct correlation). When the farmer carries out the financial planning, he controls the revenues, expenses, and costs in his production unit, increasing his success chances. But this is true only for the first two groups of variables.

Most literature on family farming focuses on the importance of agriculture's success (Costa, 2006; Michelotti, 2006; Bevilacqua, 2006). However, due to lack of managerial support, many farmers, at least in the short term, do not have the conditions and resources to use technologies in their production unit (Batalha et al., 2005). Added to this is the low level of 
formal education and the cultural issue of planning in the head or not writing down the information as aggravating the situation (Batalha et al., 2005; Santos, 2006). It largely explains the correlation values of this grouping of variables, the highest among organizational factors, which confirms previous studies' validity.

In the logistic grouping, the variables "Storage/transport x customers", "Storage x packaging", "Storage x customers", and "Storage/transport x transportation" presented the scores $0.49,0.47,043$ and 0.37 , respectively, considered all weak direct correlations. The first correlation measures farmers' difficulty in increasing and maintaining agricultural production to serve the foreign market. When farmers can store their products and transport them to sell directly in the local market, they are usually better able to serve larger customers. But this logical scheme is not perceived by the surveyed farmers, as shown by the low correlation index obtained.

The second correlation deals with the logic that the more products stored, the greater the need to conserve them, thus the greater need for packaging so that the products can have their physical integrity maintained, which significantly assists in their demand. The third correlation assumes that the more products stored, the more customers served. And finally, the fourth average correlation assumed that the greater the amount of goods stored, the greater the need for transportation to bring them to market. Again, all logistic correlations were low and straightforward. Farmers' reports say they have no way of disposing of their produce. In rare situations, the local city government makes available transport to take the production to sell in the market.

\subsection{Environmental factors}

In the economic grouping, the variables studied were "Employment x Inflation," "Access to credit x Lack of credit," "Employment x Population income," and "Inflation x Lack of credit," as shown in Table 1. The scores were 0.61 (moderate direct), 0, 48 (direct weak), 0.45 (direct weak) and 0.11 (direct weak), respectively. It means that farmers realize that the more employment, the higher the rate of inflation, but they do not realize that the greater the difficulty of access to credit, the more credit they will lack and the greater the difficulty of adapting and improving agricultural technologies production.

Lack of perception greatly influences the conduct of any business, especially in agriculture. This situation is posed by Uaiene (2011) when stating that, to increase the likelihood of family farmers adopting modern agricultural technologies, public managers must mobilize to overcome the shortcomings of the agricultural credit market and technology adoption.

The third correlation, which associates job creation with population income, seems to have been affected by the local situation's peculiarity and may be present in some way in all Amazonian smallholder communities. In Igarapé-Açu, many farmers have other sources of income, such as pensions. The gain with agriculture, especially without burning, is insufficient to maintain the farmer and his family.

The latest correlation shows that high inflation rates probably increase the lack of credit because the population's purchasing power is reduced. The economic issue, although indirectly interfering, should not be overlooked. A favorable economic environment with income, low employment inflation, and access to credit is positively associated with technology adoption and improved quality of life for family farmers (Uaiene, 2011). Anyway, this logic is not perceived by the respondents.

In the social grouping, the variables studied were "Lack of union between farmers vs. Farmers" and "Infrastructure $\mathrm{x}$ Health." The first had a score of 0.61 (moderate direct), while the second reached only 0.37 (weak direct). These results indicate that farmers perceive as a valid fact that the smaller the organization of local farmers, the fewer farmers are interested in participating in local organizations and associations.

This perception can pose several problems, such as the lack of access to cutting and milling technology for many farmers, which is restricted to a few farmers. The aggravation is even more significant when one considers that technology 
depends on resources approved in projects funded by research funding agencies. As Kawage (2006) demonstrates, social participation, the interconnectedness between social systems, exposure to interpersonal communication channels, and belonging to a high social interconnection system are factors positively associated with the early adoption of innovations in agriculture.

Table 2: Environmental factors correlated by $r$ Pearson.

\begin{tabular}{|c|c|c|}
\hline Factors and Variables & r Pearson & p-value \\
\hline $\begin{array}{l}\text { Economics } \\
\text { Employment x Inflation } \\
\text { Credit access vs. Credit failure } \\
\text { Employment x Population income } \\
\text { Inflation vs. lack of credit }\end{array}$ & $\begin{array}{l}0,61 \\
0,48 \\
0,45 \\
0,11\end{array}$ & $\begin{array}{l}0,0002 \\
0,0054 \\
0,0099 \\
0,0090\end{array}$ \\
\hline $\begin{array}{l}\text { Social } \\
\text { Farmers x Farmers lack union } \\
\text { Infrastructure x Health }\end{array}$ & $\begin{array}{l}0,61 \\
0,37 \\
\end{array}$ & $\begin{array}{l}0,0002 \\
0,0352 \\
\end{array}$ \\
\hline $\begin{array}{l}\text { Politics } \\
\text { Councilors x City Halls and Secretaries } \\
\text { Access to Local Politicians x City Halls and Secretaries } \\
\text { Access to local politicians vs. Laws that encourage }\end{array}$ & $\begin{array}{l}0,57 \\
0,44 \\
0,40\end{array}$ & $\begin{array}{l}0,0006 \\
0,0108 \\
0,0239\end{array}$ \\
\hline $\begin{array}{l}\text { Cultural } \\
\text { Do not write down information x talk to technicians } \\
\text { Change the way things are done vs. talking to technicians } \\
\text { Unplanned decisions vs. talking to technicians }\end{array}$ & $\begin{array}{l}0,41 \\
0,40 \\
0,38\end{array}$ & $\begin{array}{l}0,0202 \\
0,0238 \\
0,0338\end{array}$ \\
\hline $\begin{array}{l}\text { Environmental } \\
\text { Technology to preserve x Compensation system } \\
\text { Population awareness x Overconsumption } \\
\text { Technology to preserve x Compensation system } \\
\text { Population awareness vs. technology to preserve }\end{array}$ & $\begin{array}{l}-0,40 \\
0,62 \\
0,61 \\
0,50\end{array}$ & $\begin{array}{l}0,0265 \\
0,0001 \\
0,0002 \\
0,0035\end{array}$ \\
\hline $\begin{array}{l}\text { Demographics } \\
\text { Farmers living in the city x Young people's interest } \\
\text { Youth vs. Retired interest }\end{array}$ & $\begin{array}{l}0,38 \\
0,36 \\
\end{array}$ & $\begin{array}{l}0,0312 \\
0,0441 \\
\end{array}$ \\
\hline $\begin{array}{l}\text { Technological } \\
\text { Modern machines and equipment x Support technology }\end{array}$ & 0,50 & 0,0039 \\
\hline
\end{tabular}

Source: Authors.

In the political grouping, the variables researched were "Councilors vs. City Halls and Secretaries," "Access to local politicians vs. City Halls and Secretaries," and "Access to local politicians vs. Laws." The results obtained were as follows, respectively: 0.57 (moderate direct), 0.44 (weak direct), and 0.40 (weak direct). It means that farmers realize that the greater the councilors' lack of support, the greater the City Hall and Secretariats' lack of support. However, they do not realize that the more difficult access to local politicians, the more difficult access to City Hall and Secretaries, and the more difficult access to local politicians, the greater the difficulty of laws that encourage agriculture without burning. It seems to be related to what Kawage's (2006) study showed, that historical neglect by local government and corruption cases contributed to farmers' distrust and dissatisfaction with the local legislature. According to the author, the government in Igarapé-Açu would be more interested in serving the interests of individuals, large companies, or large farmers.

In the cultural grouping, the variables researched were "Do not write down information vs. Conversations with technicians," "Changing the way things are done vs. Conversations with technicians," and "Unplanned decisions vs. Conversations with technicians" with their scores. The correlations obtained were 0.41 (direct weak), 0.40 (direct weak), and 0.38 (direct weak), respectively. Farmers do not realize that the more they do not write down information, the less they maintain traditional production and marketing forms. When making unplanned decisions, more they need for accompanying technical assistance and rural extension. Therefore, they do not realize that assistance could help solve some difficulties in 
practicing technology without burning in agriculture. Uaiene (2011) confirmed a similar situation in a study in Mozambique. In households with access to technical assistance services, access to rural credit and agricultural associations are more likely to adopt new agricultural technologies.

In the environmental grouping, the variables studied were "Technology to preserve vs. Compensation system," "Population awareness vs. Overconsumption," "Technology to preserve x Compensation system," "Population awareness vs. technology" generated the following correlations: -0.40 (weak inverse), 0.62 (direct moderate), 0.61 (direct moderate) and 0.50 (direct moderate). The first correlation is not perceived as necessary by farmers. They do not see that the more technologies available for environmental preservation, the lower the cost of acquiring and maintaining such technologies. For them, the claim that technologies make the need for a compensation system to preserve productive areas less valid is not valid. Their perception is flawed, shared by a small number of farmers.

The second correlation suggests that the greater the consumption of goods and services, the greater the need for society's awareness of the need for environmental preservation. Farmers perceive that the high consumption of products and services implies a greater consumption of natural resources, therefore greater pressure on the environment and, consequently, greater need to raise the population's awareness to preserve natural resources.

In the demographic grouping, the variables that worked were "Farmers who lived in the city vs. Youth interest" and "Youth interest vs. Retirees," for which the following correlations were obtained: 0.38 (weak direct) and 0.36 (weak direct). The assumption tested was that the more people leave the countryside, sell their land and move to cities, the younger people are interested in city life. The assumption is that young people see how difficult the farmer's life is, with little economic and social appreciation prospects, which would lead them to lose interest in rural life. These were perceptions shared by a small number of farmers.

In the grouping technologies, the researched variables were Modern machines and equipment vs. Support technology, with a correlation score of 0.50 (moderate direct). This result confirms the assumption that the more modern machines, the more support farmers will have to practice production with non-burn agriculture. It seems to be a result that corroborates the need to replace the traditional production model with non-burning production technology.

\section{Conclusion}

This study showed that organizational and environmental factors are perceived as unimportant by family farmers who practice non-burning production to manage their production units. Moreover, this behavior is aggravated because, as farmers lack management skills and are not adequately monitored by extension technicians, there is little social learning and the possibility of change due to poor communication between these two groups of actors.

Another finding is that the value received from the sale of production is considered low. Therefore, farmers are very unmotivated to increase their working hours in the no-burn farming system, whether by hiring outside labor, family, or multitude. Regarding the productive aspect, there is a delay in the secondary vegetation crushing in the agricultural areas, causing a delay in the agricultural calendar and their dissatisfaction with the system. This fact can be attributed to the milling machine being ancient (over 20 years of use), which causes constant breakage of parts and the difficulty of maintenance due to lack of logistic support of parts and local human.

Although farmers are not articulated to collectively sell production and access to other markets, as they sell to intermediaries, they are aware of other possibilities for selling and quoting the prices of crops they produce with non-burn agriculture. Another important aspect that characterizes the system is that there is no financial planning and monitoring, so they do not know how much they raise, spend and profit or lose in the activity, reinforcing the system of financial difficulty of agriculture without burning in the region. The market served is also restricted to the middlemen who buy the product and take 
the farmer's property. No storage and transportation system can sustain the increase in crop production with non-burning agriculture.

Farmers have difficulty accessing credit as many have debts from other agricultural finance programs such as Pronaf, an environmental barrier even if they do not have the managerial knowledge to apply these resources to their agricultural production. No burning. It is compounded by low collective association, disunity, distrust among farmers, local infrastructure such as poorly maintained roads, and lack of local political support for burn-free agriculture. The local system is still characterized by informality in the planning and decision-making process. Due to difficulties and lack of resources, some farmers moved to the city. It increases the interest of young people in the city and not in the countryside. Modern machinery and equipment are lacking to support non-burn agriculture in the region.

These results describe a reality far removed from the capitalist system of production. They denote a pre-capitalist mindset, in which the surveyed family farmers do not perceive the critical variables of the functioning of capitalist organizations. And this is probably the same mindset as almost all Amazonian family farmers. It does not mean, however, that this mindset is terrible or good. It is far from the pretensions of this study any value judgment.

How can a production system, whatever it be, succeed in a market economy system if the operation of these production units materialized in their management process, does not recognize the critical operating variables of these organizations as necessary? How to make a production agent successful that does not match the other agents' prevailing mindset in the system? How to make someone who does not understand how important the management tools and procedures manage your production unit?

This study's main finding is that the cause of family farming failure is the lack of awareness of the importance of organizational (internal environment) and environmental (external) factors in your business's success. Therefore, it suggests that these ventures' success, as verified in successful agricultural production systems in other regions, such as Santa Catarina, is due to the sharing of the same mentality, the market mentality, lacking in the researched reality.

\section{References}

Anselmi A. A. (2012) Adoção da agricultura de precisão no Rio Grande do Sul. Unpublished master thesis, Universidade Federal do Rio Grande do Sul, Brazil.

Bandiera, O., \& Rasul, I. (2006) Social networks and technology adoption in Northern Mozambique. The Economic Journal, 166, 869-902.

Batalha, M. O., Buainain, A. M., \& Souza Filho, H. M. (2005) Tecnologia de gestão agricultura familiar. In Souza Filho, H. M., \& Batalha, M. (Org) Gestão integrada à agricultura familiar. São Carlos: Edufscar.

Bervald, C. P. (2001) Avaliação da qualidade do mulch proveniente da trituração da vegetação secundária através da tritucap e fresadora florestal AHWI. Belém: Embrapa.

Besley, T., \& Case, A. (1993) Modelling technology adoption in developing countries. American Economic Review, 83:396-402.

Bevilacqua, L. I. (2006) Custos de trituração da tecnologia de cobertura morta no nordeste paraense: a experiência do Projeto Shift Capoeira em três municípios. In: Costa, F. A., Hurtienne, T., \& Kahwage, C. (Org) Inovação e difusão tecnológica para sustentabilidade da agricultura familiar na Amazônia: resultados e implicações do Projeto SHIFT Socioeconômica. Belém: UFPA/NAEA.

BNDES (2011) Sistema Tipitamba: transferência de tecnologias para recuperação de áreas alteradas para agricultura familiar no Estado do Pará. Proposta de projeto. Belém: BNDES.

Cella, D. (2002) Caracterização dos fatores relacionados ao sucesso de um produtor rural. Unpublished master thesis, Universidade de São Paulo, Brazil.

Conley, T. G., \& Udry, C. R. (2002) Learning about a new technology: pineapple in Ghana. Working paper, University of Chicago.

Costa, F. A. (2006) Capoeiras, inovações e tecnologias rurais na Amazônia. In: Costa, F. A., Hurtienne, T., \& Kahwage, C. (Org) Inovação e difusão tecnológica para sustentabilidade da agricultura familiar na Amazônia: resultados e implicações do Projeto SHIFT Socioeconômica. Belém: UFPA/NAEA.

Costa, N. L. (2005) Desenvolvimento sustentável e a agricultura itinerante. Embrapa.

Cribb, A. Y., Cribb, S. L. S. P., Freire Junior, M., \& Silva, F. T. (2011) Adoção tecnológica e gestão cooperativista: um estudo de caso na agricultura familiar. Cadernos de Ciência \& Tecnologia, Brasília, 28(1), 133-157. 
Denich, M. (1991) Estudos da importância de uma vegetação secundária nova para o incremento da produtividade do sistema de produção na Amazônia oriental brasileira. Eschborn: Embrapa/CPATU-GTZ.

Denich, M. et al. (2004) Mechanized land preparation in forest-based fallow systems: the experience from Eastern Amazonia. Agroforestry Systems, 61-62, 91106.

Dereti, R. M. (2009) Transferências e validação de tecnologias agropecuárias a partir de instituições de pesquisa. Desenvolvimento e Meio Ambiente, 19, 2940 .

Diaz, M. C. V., Nepstad, D., Mendonça, M. J. C, Mota, R. S., Alencar, A., Gomes, J. C., \& Ortiz, R. A. (2002) O preço oculto do fogo na Amazônia: custos econômicos associados ao uso do fogo. IPAM.

Embrapa (2002) Projeto Tipitamba: intensificando o manejo da capoeira com sustentabilidade: produzir sem queimar. Embrapa.

Feder, G., Just, R. E. \& Zilberman, D. (1985) Adoption of agricultural innovations in developing countries: a survey. Economic Development and Cultural Change, 33(2), 285-298. https://dx.doi.org/10.1086/451461.

Figueiredo Filho, D. B., \& Silva Júnior, J. A. (2009) Desvendando os mistérios do coeficiente de correlação de Pearson (r). Revista Política Hoje, 18(1), 115146.

Foster, A., \& Rosenzweig, M. (1995) Learning by doing and learning from others: human capital and farm household change in agriculture. Journal of Political Economy, 103(6), 1176-1209. https://doi.org/10.1086/601447.

Gaidos M., Mracková, M., Elfmarková, N., Rektorová, I., \& Mikl, M. (2015) Comparison of canonical correlation analysis and Pearson correlation in restingstate FMRI in patients with Parkinson's disease. Clinical Neurophysiology, 126(3), e47-e48.

Ghandim, A. K. A., \& Pannell, D. J. (1999) A conceptual framework of adoption of an agricultural innovation. Agricultural Economics, 21, 145-154.

Gil, A. C. (2002) Como elaborar projetos de pesquisa. Atlas.

Gliessman, S. R. (2001) Agroecologia: processos ecológicos em agricultura sustentável. EdUFRGS.

Hölscher, D. (1997) Dynamic of soil chemical parameters in shifting agriculture in the Eastern Amazon region. Agriculture Ecosystems and Environment, 66, 153-163.

Kato, O. R, Kato, M. S. A., Sá, T. D. A., \& Figueiredo, R. (2006) Plantio direto na capoeira: sistemas agroflorestais: bases científicas para o desenvolvimento sustentável. Campos: Universidade Estadual do Norte Fluminense.

Kawage, C. (2006) Campesinato e capital social comunitário em Igarapé-Açu. In: Costa, F. A., Hurtienne, T., \& Kahwage, C. (Orgs.) Inovação e difusão tecnológica para sustentabilidade da agricultura familiar na Amazônia: resultados e implicações do Projeto SHIFT Socioeconômica. UFPA/NAEA.

Limas, M. F., Santiago, M. C., \& Nascimento-e-Silva, D. (2020). Analysis of the introduction of scientific articles published in Brazilian journals with Qualis A2 from the administration area. Research, Society and Development, 9(10), e7059109097. http://dx.doi.org/10.33448/rsd-v9i10.9097.

Ma, T., Grübler, A., \& Nakamori, Y. (2009) Modeling technology adoptions for sustainable development under increasing returns, uncertainty, and heterogeneous agents. European Journal of Operational Research. 195(1), 296-306.

Megginson, L. C., Mosley, D. C., \& Pietri Junior, P. H. (1998) Administração: conceitos e aplicações. Harbra.

Michelotti, F. (2006) Os custos da trituração da capoeira no Nordeste Paraense: uma primeira aproximação. In: Costa. F. A., Hurtienne, T., \& Kahwage, C. (Org) Inovação e difusão tecnológica para sustentabilidade da agricultura familiar na Amazônia: resultados e implicações do Projeto SHIFT Socioeconômica. UFPA/NAEA.

Moxley, R. L., \& Lang, K. B. (2006) The importance of social context influences on new farm technology sustainability: community and sub-community characteristics in Jamaica. Technology in Society, 28, 393-406.

Nascimento-e-Silva, D. (2011) Compreendendo o processo gerencial. Ifam.

Nascimento-e-Silva, D. (2012) Manual para redação de trabalhos acadêmicos: position papers, ensaios teóricos, artigos científicos e questões discursivas. Atlas.

Nascimento-e-Silva, D. (2013) Proposição de uma sistemática de avaliação de aprendizagem na formação de administradores com base no processo gerencial. Rev. Adm. UFSM, 6(4), 640-657. https://dx.doi.org/ 10.5902/198346595826.

Nascimento-e-Silva, D. (2020a). Manual do método científico-tecnológico: edição sintética. DNS Editor.

Nascimento-e-Silva, D. (2020b). Regras básicas para redação acadêmica. DNS Editor.

Nascimento-e-Silva, D., Brito, Z. M., Dossena, S. M., Bentes, A. C. L., Queiroz, A. E. S. F., Santos, A. B. G. M., \& Gomes, V. S. (2020a). Analysis of the effectiveness of the managerial process in a federal institution of education, science and technology in Northern Brazil. Brazilian Journal of Business, 2(2), 1420-1440. https://dx.doi.org/ 10.34140/bjbv2n2-037.

Nascimento-e-Silva, D., Valente, S. B. C., Simões, C. S., Soares, M. L., \& Pereira, D. R. (2020b). Variables that affect the product quality: A study in an Electronic industry of the Manaus industrial pole, Brazil. Journal of Business and Management, 22(2), 31-37. https://dx.doi.org/10.9790/487X-2202043137.

Nepstad, D. C., Uhl, C., Pereira, C. A., \& Silva, J. M. C. (1996) A comparative study of tree establishment in abandoned pasture and mature Eastern Amazon forest. Oikos, 76, 25-39. https://dx.doi.org/10.2307/3545745. 
Oliveira, C. D. S. (2002 Percepção de agricultores familiares na adaptação do sistema de cultivo de corte e trituração. Unpublished master thesis, Universidade Federal do Pará, Brazil.

Oliveira, S. L. (1997) Tratado de metodologia científica: projetos de pesquisa, TGI, TCC, monografias, dissertações e teses. Pioneira.

Pavarina, P. R. J. P., Cella, D., \& Peres, F. C. (2003) A percepção das atividades administrativas: produtores rurais e profíssionais da assistência técnica. In Annals of XLI Congresso Brasileiro de Economia e Sociologia Rural. Juiz de Fora, Brazil.

Ramalho, J. P., \& Contini, E. (1987) Considerações teóricas sobre o mercado de tecnologias agropecuárias. Caderno de Difusão Tecnológica, 4(1), 39-57. Rauniyar, G. P., \& Goode, F. M. (1992) Technology adoption on small farms. World Development, 20(2), $275-282$.

Sá, J. A. S., Cruz, A. L. G., \& Nascimento-e-Silva, D. (2004) Fatores para o processo de formação e gestão de alianças estratégicas do tipo consórcio em pequenas e médias empresas construtoras: um estudo de caso. Annals of I Conferência Latino-Americana de Construção Sustentável - X Encontro Nacional de Tecnologia do Ambiente Construído, São Paulo, Brazil.

Salleh, F. H. M., Arif, S. H., Zainudin, S., \& Firdaus-Raih, M. (2015) Reconstructing gene regulatory networks from knock-out data using Gaussian noise model and Pearson correlation coefficient. Computational Biology and Chemistry, 59, 3-14.

Sampaio, C. A. (2008) Alianças estratégicas como alternativa de gestão de sistemas agroflorestais sequências sustentáveis em agroecossistemas da Amazônia: uma proposta para implementar agricultura de corte e trituração no âmbito da agricultura familiar no nordeste paraense. Unpublished Ph.D. thesis, Universidade Federal Rural da Amazônia, Brazil.

Sanders, J. H., \& Lynam, J. K. (1982) Evaluation of new technology on farms: methodology and some results from two crop programmers at CIAT. Agricultural Systems, 9, 97-112.

Santana, A. C., Carvalho, D. F., \& Mendes, F. A. T. (2008) Análise sistêmica da fruticultura paraense: organização, mercado e competitividade empresarial. Belém: Banco da Amazônia.

Santos, L. O. L. (2006) Percepção de um grupo de agricultores da localidade São João do município de Marapanim (PA) sobre o método de corte e trituração como alternativa ao método tradicional de corte e queima da vegetação secundária. Unpublished master thesis, Universidade Federal do Pará, Brazil.

Sensuse, D. I., Cahyaningsich, E., \& Wibowo, W. C. (2015) Identifying knowledge management process of Indonesian government human capital management using analytical hierarchy process and Pearson correlation analysis. Procedia Computer Science, 72, $233-243$.

Silva, R. O., Ferreira, J. A. O. A., Rivera, J. A., Souza, S. S., \& Nascimento-e-Silva, D. (2020). Definition, elements and stages of elaboration of research protocols. Research, Society and Development, 9(10), e3189108721. http://dx.doi.org/10.33448/rsd-v9i10.8721.

Sommer, R., Vlek, P. L. G., Sá, T. D. A., Coelho, R. F. R., \& Folster, H. (2004) Nutrient balance of shifting cultivation by burning or mulching in the Eastern Amazon: evidence for sub-soil nutrient accumulation. Nutrient Cycl. in Agroecosystems, 68, 257-271.

Stoner, J. A. F., \& Freeman, R. E. (1999). Administração. LTC.

Uaiene, R. N. (2011) Determinantes para a adopção de tecnologias agrícolas em Moçambique. Maputo, s.n.

Vergara, S. C. (2007) Projetos e relatórios de pesquisa em administração. Atlas. 